\section{Hungary shows how it's done}

HUNGARIAN agriculture is flourishing, much to the surprise of Soviet investigators, solely on the basis of economic incentives and guidelines. This is the gist of a report by a Soviet interministerial council set up at the end of 1981 to study economic management systems in the Soviet bloc, which has just produced its first report.

Except in Poland (where 85 per cent of agriculture remains in private hands), the standard Comecon pattern for agriculture, as for other production sectors, is one of centrally set targets and directives with which the agricultural cooperatives, collective and state farms must comply. Since Hungary has the most flourishing agriculture of the whole Comecon bloc, its success inevitably provokes heartsearching among the advocates of classical socialist central planning.

In fact, a considerable amount of lowprofile planning underlies Hungary's agricultural success. Having experienced farming by directive during the Rokosi regime (1948-56), which tried, among other things, to make the country selfsufficient in such exotic products as cotton and citrus fruit, the trend of recent years has been to leave the agricultural collectives to decide what to grow but to encourage them to grow particular crops by appropriate bonuses. The scheme has not been without its blunders - in the mid-1970s, for example, bonuses were paid on the gross weight of sugar beet produced, leading to a waste of fertilizers in producing grant beet with only a low sugar content - but this was easily rectified by relating the bonuses to sugar yield.

Moreover, in the late 1970 s, a detailed interdisciplinary survey was carried out with the cooperation of the Hungarian Academy of Sciences to determine the best crop for each region of the country. The survey, completed in April 1981, became the new basis for the price structure of agricultural purchases and bonuses.

To the Soviet Union, with its ever declining agricultural production, the Hungarian model must appear pragmatically tempting (although its introduction would doubtless entail some revision of Party doctrine). In a recent interview on Moscow radio, Academician Peter Vavilov, president of the All-Union Academy of Agricultural Science, blamed the Soviet Union's agricultural plight largely on "shortcomings in the functioning of the economic mechanism", although the decline in humus content of the soil, widespread erosion and a lack of capital investment and high grade fertilizers also contributed to the decline.

The main fault, according to Vavilov, was, however, the splitting up of management functions and the loss of unified control. He called for an end to "bureaucratic attitudes, parochial preoccupations, out-

\section{Ecology groups united} and corporate crime". mental issues. any parliamentary seats. level of the management process. So far, however, there is no sign of improvement - and 1983, the 50th anniversary of the artificial famine in Ukraine produced by the forced introduction of collectivization, is a grim anniversary for Soviet agricultural planners.

In such circumstances, their "surprise" at the success of the Hungarian system may well be gradually reflected in unpublicized but significant changes in the farm price system. moded methods of work, and inertia and laziness in economic thinking". He did not suggest that a relaxation of control on the Hungarian model should be introduced.

Indeed, the 20-year food programme, introduced in 1981 to increase food production in the Soviet Union itself, advocates a strengthening of control at every

\section{Call for end to UK secrets act}

A CAMPAIGN to allow greater public right of access to governmental information was launched in professional style in London last week by Mr Des Wilson, chairman of both Friends of the Earth (FoE) and the Campaign for Lead-free Air (CLEAR). FoE is currently benefiting from campaigning skills lent by Ralph $\mathrm{Nader}$, the veteran American champion of citizens' rights. Nader called for civil servants and others to follow their consciences and be prepared to break the law if this was necessary to provide the public with information that would "prevent governmental

The aim of the new campaign is to replace the Official Secrets Act of 1911 with a Freedom of Information Act similar to that in the United States. Seen against the backdrop of an imminent general election, the campaign has implications for Britain's major political parties courting the "green" vote. Mr Michael Foot, leader of the Labour Party, has recently made several speeches highlighting environ-

Mr Wilson said that the time was not yet ripe for the formation of a new green party along the lines of the West German party. The number of votes polled by candidates standing for the existing Ecology Party in recent elections has been derisory, and FoE is instead seeking to further its aims within the major political parties. In the United Kingdom, "minority" parties are hindered by the first past the post system, and the even share of the vote gained by the German party would not give a UK green party

Both the Labour Party and the Liberal Party say they have repeal of Section 2 of the Official Secrets Act high among their priorities for action in government. The ef-

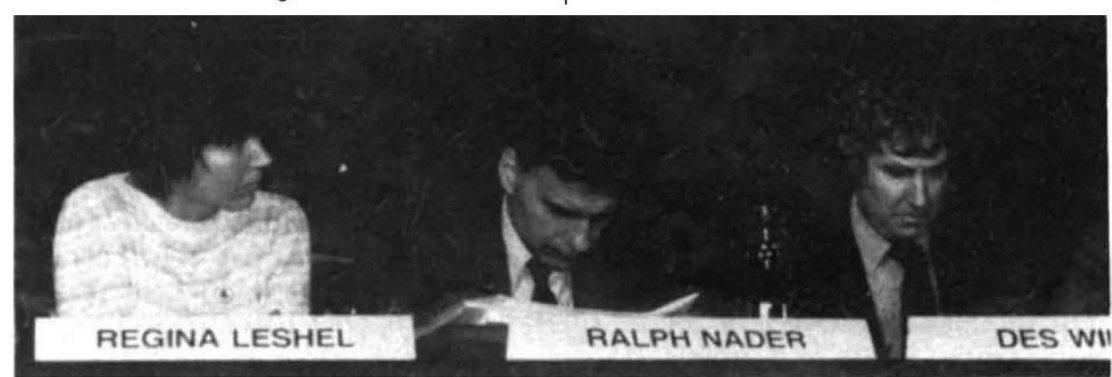
has yet to be published. common.
A gathering of greens, from West Germany, the United States and Britain.

fect of this section of the act is to make it illegal to receive almost any internal government information, so much apparently innocuous information remains classified as secret. Mr Clement Freud, Liberal MP for Ely, attempted to bring in a Private Member's Bill to reverse this position in the last days of the Labour Government. He pointed out last week that at the moment it is impossible to obtain information on which hotels have been certified as fireworthy, for example. However, Mr John Wheeler, honourary secretary of the Conservative Party's Home Affairs Committee, described FoE's appeals for legislation leading to more open government as "incredibly naîve". He argued that in Britain it is the role of Members of Parliament to scrutinize the operation of government and claimed that comparisons with the United States were misleading. The Conservatives have no commitment to more open government at present, but their policy document for the general election

The major event in FoE's 3-day publicity programme last week was the "Green Rally", which was attended by 3,000 environmentalists in London. They were in high spirits, doubtless inspired by the government's recent decision to ban lead from petrol. Speakers included Nader, Wilson, Mrs Joan Ruddock of the Campaign for Nuclear Disarmament (CND) and Regina Leshel of the German greens. CND maintains it will not be taking a party political stance in the election run-up and says there was no significance in Mrs Ruddock's sharing a platform with the Ecology Party. $\mathrm{Mr}$ Wilson said at the rally that the aim was simply to bring greens together in closer cooperation over the issues they shared in

Tim Beardsley 